\title{
Land Use and Land Cover Change as an Indicator of Watershed Urban Development in the Kenyan Lake Victoria Basin
}

\author{
Dancan Otieno Onyango $^{1 *}$, Christopher O. Ikporukpo ${ }^{2}$, John O. Taiwo ${ }^{2}$, Stephen B. Opiyo ${ }^{3}$ \\ ${ }^{1}$ Pan African University Life and Earth Sciences Institute (PAULESI), University of Ibadan, Ibadan 200284, Oyo State, \\ Nigeria \\ ${ }^{2}$ Department of Geography, University of Ibadan, Ibadan 200284, Oyo State, Nigeria \\ ${ }^{3}$ Department of Environment and Natural Resources, Faculty of Agriculture and Natural Resources Management, Kisii \\ University, P.O Box 408 - 40200, Kisii 40200, Kenya
}

Corresponding Author Email: dancanthomas@gmail.com

https://doi.org/10.18280/ijsdp.160213

Received: 28 January 2021

Accepted: 30 March 2021

\section{Keywords:}

watershed urbanization, land use/land cover change (LULC), Kenyan Lake Victoria basin, Landsat imagery, supervised classification, sustainable development

\begin{abstract}
The socio-economic and ecological value of Lake Victoria is threatened by significant regional development and urbanization. This study analyzed spatial-temporal land use/land cover changes in the Kenyan Lake Victoria basin from 1978-2018 using Landsat 3, 4-5 and 8 imagery, with a view to identifying the extent and potential impacts of urbanization on the basin. Supervised image classification was undertaken following the Maximum Likelihood algorithm to generate land use/land cover maps at ten-year intervals. Results indicate that the basin is characterized by six main land use/land cover classes namely, agricultural land, water bodies, grasslands and vegetation, bare land, forests and built-up areas. Further, the results indicate that the basin has experienced net increases in built-up areas $(+97.56 \%)$, forests $(+17.30 \%)$ and agricultural land $(+3.54 \%)$ over the last 40 years. During the same period, it experienced net losses in grassland and vegetation $(-37.36 \%)$, bare land $(-9.28 \%)$ and water bodies $(-2.19 \%)$. Generally, the changing landscapes in the basin are characterized by conversion of natural environments to built-up environments and driven by human activities, urban populations and public policy decisions. The study therefore recommends the establishment of a land use system that creates a balance between the ecological realm and sustainable development.
\end{abstract}

\section{INTRODUCTION}

Land use refers to the ways in which human beings use and manage land and its re-sources as a way of sustaining their lives [1]. It differs from land cover, which refers to the biological and physical materials that exist on the surface of land, whether natural or manmade $[2,3]$. Land use includes agricultural, residential, commercial or any other anthropogenic uses of the land by people. This implies the exploitation of land, and the associated resources, which translates into denaturalization of the land [1]. Land cover, on the other hand, includes both the natural and man-made/caused changes which occur on the surface of land over time. Land use and land cover are often used together as land use/land cover change (LULC), which is regarded as the product of natural and socio-economic aspects of an area and their accompanying anthropogenic manipulation in space and time [4].

Mostly, LULC involve converting naturally existing land into agricultural land or build-up areas for residential or commercial purposes. Depending on where and how LULC change takes place, it can be detrimental to the integrity of the natural resources or it could be beneficial. Studies have established the negative impacts of changes in LULC to be in the form of losses in forest cover, biodiversity, and increased frequency of flooding disasters as well as global warming [5-
7]. Land use/land cover change can be beneficial in terms of provision of food, living spaces and materials such as fuel wood for human use [8].

LULC assessment through remote sensing has gained extensive usage globally as a research tool for monitoring changes in the environment and natural resources for management purposes [9]. The widespread application of remote sensing is because it enables understanding of interactions between the environment and anthropogenic activities. Further, remote sensing is widely used due to the spatial extent of most satellite images and the long timeframe of imagery collection, which enables analysis of change over a longer period of time and wider geographical coverage [10]. Studies have shown that remote sensing can accurately map out the distribution pattern of land use/land cover over enormous geographical area $[11,12]$.

The assessment of LULC changes using remote sensing techniques has been used since mid-1970s in both developing and developed worlds [13], especially in the fields of agriculture and environmental studies [14-16], to generate insights for decision-makers on the planning and management of the environment [17]. In Brazil, increasing urbanization trends due to land use and land cover changes in the Middle Rio Grande was evaluated through remote sensing of the declining upland mixed vegetation cover [18]. A study in the United Kingdom using remote sensing evaluated the 
environmental impacts of urban land use and land cover change in Merseyside and found that the increasing built-up areas has caused the decline in green spaces [19]. In Central Europe reduction in species diversity due to urban growth was reported from an evaluation of land use impacts on the environment via remote sensing [20]. In Southern Asian countries of India and China, rapid urbanization has been reported from the assessment of the impacts of land use and land cover change on the ecosystem services conducted through remote sensing $[21,22]$. In the developing world, combined GIS and remote sensing techniques has been used in analyzing urbanization trends from the changes in land use and land cover in the Blue Nile basin in Northwest Ethiopia [23], White Nile basin in Sudan [24], Murchinson Bay catchment of the Ugandan Lake Victoria basin [25] and Azrou Forest in the Central Middle Atlas of Morocco [26] among others.

In Kenya, LULC changes have been studied on a diversified range of terrains, from watersheds and river basins [27], to the forests, lakes and water towers within the country [28]. Some of the most recent studies covered the unplanned human settlements of Were et al. [28], forested highlands [29] and the drainage basins along the shores of Lake Victoria [27, 30]. The unanimous conclusions derived from all these studies is that land use/land cover changes are occurring at a high rate in different parts of the country for different reasons. Some changes occur to pave way for built-up areas [31,32] while others happen to create space for agriculture and settlements [27-29]. Despite these diverse studies in Kenya, the land use and land cover dynamics of several Kenyan landscapes having important natural resources and ecosystems, such as the Lake Victoria basin, have never been evaluated. The knowledge gaps still remain to be filled with more studies through the application of remote sensing techniques.

The Lake Victoria basin, shared among three East African countries, provides land resources which support more than 25 million human inhabitants [33], through water provision, agricultural production and fishing [34]. Considered the greatest natural re-source in the East African region [35], this basin is one of the regions in the country that has faced rapid LULC changes over the years. In spite of its global significance, land degradation in the basin has been estimated to be affecting over $60 \%$ of the area [33]. The changes in land use and land cover within the lake region have altered the hydrology of many rivers within the basin and ultimately the lake itself $[30,36]$. The lake is characterized by various urban centers that have developed over the years from small settlements, including one large city, Kisumu. This has escalated with the devolved system of governance adopted by Kenya in 2010, following promulgation of a new constitution, which has seen most development shift to the counties/regions.

As these lakeside towns continue to grow in population and socio-economic activity, the lake is likely to bear some environmental impacts. However, no studies have explicitly quantified the extent of urbanization happening within the Lake Victoria basin and the environmental impacts it has on the ecological health of the Lake Victoria ecosystem. Therefore, as an exploratory study into the extent and potential impacts of watershed urbanization, this study sought to analyze land use and land cover changes in the Kenyan basin of Lake Victoria from 1978-2018. The information produced from this study is expected to aid management decision making in the region for sustainable environmental management of the lake.

\section{METHODOLOGY}

\subsection{Study area}

Lake Victoria is located along the Equator between latitudes $0^{\circ} 20^{\prime} \mathrm{N}-3^{\circ} \mathrm{S}$ and longitudes $31^{\circ} 39^{\prime} \mathrm{E}-34^{\circ} 53^{\prime} \mathrm{W}$; and an average elevation of 1134 meters above sea level. The lake is shared among the three East African countries, Kenya (6\%), Uganda (45\%) and Tanzania (49\%) [35, 37]. The lake is considered the second largest fresh water body in the world carrying approximately $2750 \mathrm{~km}^{3}$ of water by volume within a total surface area of $68,000 \mathrm{~km}^{2}$ [35]. With an average depth of 40 meters and a maximum depth of 84 meters, Lake Victoria is considered relatively shallow [38]. Located in a region experiencing an average annual rainfall of $900 \mathrm{~mm}-2600 \mathrm{~mm}$, direct precipitation represents the major source (about $80 \%$ ) of water in the Lake Victoria. The rest of the water comes from draining streams and rivers. The White Nile is the major outlet of Lake Victoria, flowing northwards from Uganda to Egypt. The basin experiences mean annual evaporation rates of $1100 \mathrm{~mm}-2400 \mathrm{~mm}$, making the water balance of the lake to be primarily characterized by precipitation and evaporation [39].

In addition to the lake/water surface, Lake Victoria has a catchment area of about 195,000 $\mathrm{Km}^{2}$ which spans beyond Kenya, Uganda and Tanzania to Rwanda and Burundi. About $22 \%\left(43,000 \mathrm{Km}^{2}\right)$ lies in Kenya. This study focused only on the Kenyan portion of the lake's basin, specifically on the five administrative counties that immediately border the lake. These include Busia, Migori, Kisumu, Siaya and Homabay (Figure 1). The counties are regional administrative units of the Republic of Kenya and therefore form the basis for spatial LULC analysis. These counties cover a total area of about $16,000 \mathrm{Km}^{2}$ which, for the purpose of this study, is hereafter referred to as the Kenyan Lake Victoria Basin (KLVB). The KLVB is located on the western region of Kenya. The KLVB experiences inflows in the form of rivers including Sondu Miriu, Yala, Awach and Nzoia, among others.

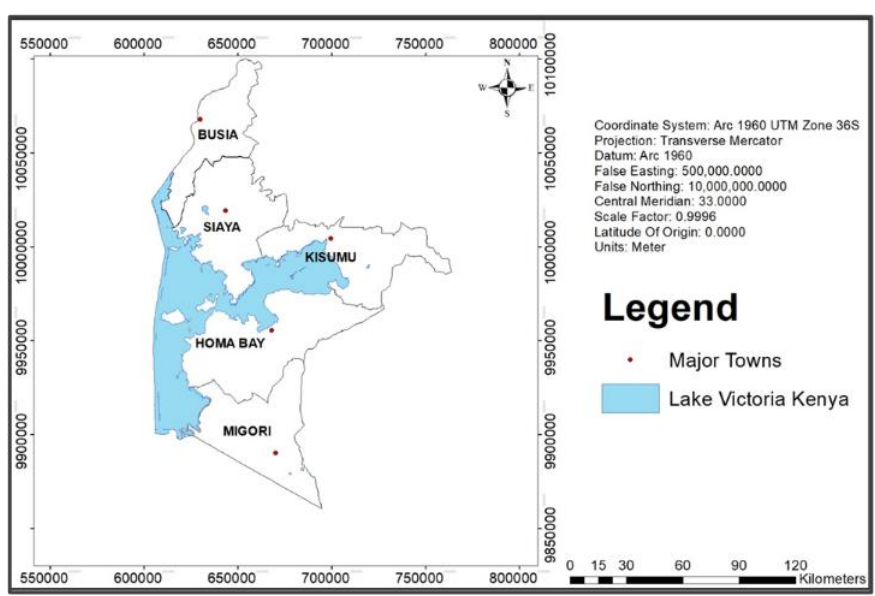

Figure 1. Map of Kenyan Lake Victoria Basin (KLVB)

\subsection{Research methods}

\subsubsection{Data sources and acquisition methods}

In order to analyze the spatial-temporal LULC changes in KLVB for the last four decades (1978-2018) at a decadal interval, remote sensing and GIS techniques were employed. The study utilized the following satellite imageries: Landsat 3 Multispectral Scanner (MSS) acquired for the month of January for the year 1978, Landsat 4, 5 Thematic Mapper (TM) 
acquired for the month of January for the years 1988, 1998 and 2008, and Landsat 8 OLI -TIRS (Operational Land Satellite The study utilized the following satellite imageries: Landsat 3 Multispectral Scanner (MSS) acquired for the month of Thematic Infrared Sensor) acquired for the month of January for the year 2018 .

All the Landsat imageries used in this study were freely obtained from the United States Geological Survey (USGS) website: www.earthexplorer.usgs.gov. Table 1 provides further details on the Landsat satellite imageries. To enhance consistency and accurate interpretation, all satellite imageries were acquired for the dry season (January) because they are characterized by little to no cloud cover and less moisture content hence minimal reflectance.

Table 1. Properties of the Landsat satellite imageries used for the LULC study

\begin{tabular}{|c|c|c|c|c|c|c|c|}
\hline YEAR & Sensor & Path/Rov & quisition D & & (\%) & Seas & Source \\
\hline 1978 & Land sat 3 MSS & $170 / 60$ & Jan, 1978 & 30 & 0 & Dry & USGS \\
\hline 1988 & Land sat 4,5 TM & $170 / 60$ & Jan, 1988 & 30 & 1 & Dry & USGS \\
\hline 1998 & Land sat 4,5 TM & $170 / 60$ & Jan, 1998 & 30 & 1 & Dry & USGS \\
\hline 2008 & Land sat 4,5 TM & $170 / 60$ & Jan, 2008 & 30 & 0 & Dry & USGS \\
\hline 2018 & and sat 8 OLI-TIRS & $170 / 60$ & Jan, 2018 & 30 & 0 & Dry & USGS \\
\hline
\end{tabular}

\subsubsection{Data Pre-processing}

After acquisition, all the imageries were imported into ERDAS Imagine 2015 Version for pre-processing. Preprocessing was done to systematically correct the images and to enhance their visualization and interpretability. Firstly, appropriate bands were layer stacked together to form one single composite image to bring out the true color image of the scene. The bands were combined in the following order for different Landsat images: Landsat 4-5 Thematic Mapper (Bands 1, 2, 3,4,5,6 and 7); Landsat 7 (Bands 1, 2,3,4,5, 7 and pan sharpened with Band 8 (Band 6 was left out due to its default setting in Landsat 7); and Landsat 8 (Bands 2,3,4,5,6,7 and pansharpened by band 8 ). The following bands were left out in Landsat 8 due to the following reasons; Band 1-Its mainly used to map coast waters, Band 9 - It represents cirrus cloud, and Bands $11 \& 12$ are thermal bands [40].

After layer stacking, pan sharpening was done to enhance visualization. Images with panchromatic resolution, mainly Landsat 7 and 8 were pansharpened using panchromatic bands to increase their spatial resolution from $30 \mathrm{~m}$ to $15 \mathrm{~m}$. This was followed by radiometric correction. The main radiometric correction carried out was haze reduction to reduce the impacts of haze captured on the images [2]. Mosaicking was carried out to merge three separate satellite raw images and the area of interest was clipped from the mosaic using the extent of the Lake Victoria Region of Kenya.

\subsubsection{Data processing and analysis}

To obtain the land use/land cover, supervised classification using Maximum Likelihood algorithm [2] was carried out using ERDAS Imagine. In the supervised classification process, the LULC classes were defined as agricultural land (comprising surface areas dedicated to the cultivation of crops, vegetables and fruits), water bodies (comprising are-as under rivers, lakes, swamps and wetlands), grasslands \& vegetation (comprising areas covered by grasses, shrubs and bushes), bare land (comprising exposed rocky or soil sur-faces lacking any vegetation cover), forests (comprising areas under naturally occurring or planted indigenous and exotic trees) and built-up areas (comprising areas under residential, commercial, industrial and infrastructural establishments).

Six (6) ground-truth polygons, each representing the six LULC classes, were randomly selected and digitized based on aerial photographs and visual analysis of geographical locations on Google Earth maps. Each training sample polygon used in classification process contained 17 pixels, bringing the total training sample to 100 pixels. The training sample polygons which were found with unwanted pixels were thrown out and replaced with the new ones with wanted spectral signatures. After training the image using signature editor, the Maximum Likelihood algorithm was run a couple of times to obtain the defined classes in the image. Due to the medium resolution of the images used, Pixel based classification was used to classify images of the study years separately. After producing the land use/land cover, the images were loaded in the ArcGIS to design the final LULC maps of 1978, 1988, 1998, 2008 and 2018 with appropriate cartographic elements. Based on the processed data, the study identified six LULC classes in the Lake Victoria Basin.

\subsubsection{Post-processing}

In remote sensing, accuracy assessment is necessary in determining the quality of the information obtained from the satellite imageries [41]. It involves a comparison between the information from ground reference points to that from the classified maps. In this process, a confusion or error matrix comprising important statistical elements of producer's accuracy, user's accuracy, overall accuracy, Kappa statistics/coefficient [42] were produced for each image. After obtaining supervised classified images that represent the various LULC classes for this study, accuracy assessment was carried out for the study years. The accuracy assessments for the classification images of 1978, 1988, 1998 and 2008 were done using historical data obtained through analysis of the available ancillary data (including topographical maps) and sampling of past backdated Google Earth images of the area of interest.

All the ground truthing, conducted using Google Earth images to ascertain what was on the ground during those past study years, were carried out on the exact year and season the Landsat image was captured. For the 2018 classification image, accuracy assessment was accomplished by checking the remote sensed data against the ground-truthing data obtained during the field visit done during the dry season in 2018. During fieldwork, 100 randomly selected ground reference points distributed within the study area were used to cover the 2018 classification image. During verification, the class value where each random point located on the image was specified and reference made with a medium-resolution image to ascertain the accuracy of a pixel where the random points are located. Finally, accuracy assessment criteria (namely producer accuracy, user accuracy, overall accuracy and Kappa coefficient) were computed for each of the LULC classes in the classified maps following the established formulas [43] 
and a report in form of confusion (error) matrix produced for each of the LULC maps.

After supervised classification and accuracy assessments, change detection analysis was carried out to determine the coverage for the various LULC classes in each map through consideration of the pixel count against the total area of the basin. These areal coverage estimations were presented in square kilometers as well as percentages for each year (1978, 1988, 1998, 2008 and 2018). Trends of spatial-temporal changes for the LULC in the KLVB were then determined to indicate the scale of environmental changes in the watershed.

\section{RESULTS AND DISCUSSION}

\subsection{Classification and distribution of LULC changes}

Six classes of LULC were identified in the Lake Victoria basin. The classified LULC maps of 1978 (Figure 2), 1988 (Figure 3), 1998 (Figure 4), 2008 (Figure 5), and 2018 (Figure 6) show that the basin is characterized by water bodies, grasslands \& vegetation, forest cover, built-up areas, bare land and agricultural land. This is in agreement with a previous study [44] which had identified the same LULC types on the Ugandan side of Lake Victoria Basin. Based on the LULC maps, the areal coverage of the various LULC classes with respect to time were determined and presented in Table 2 and Figure 7.

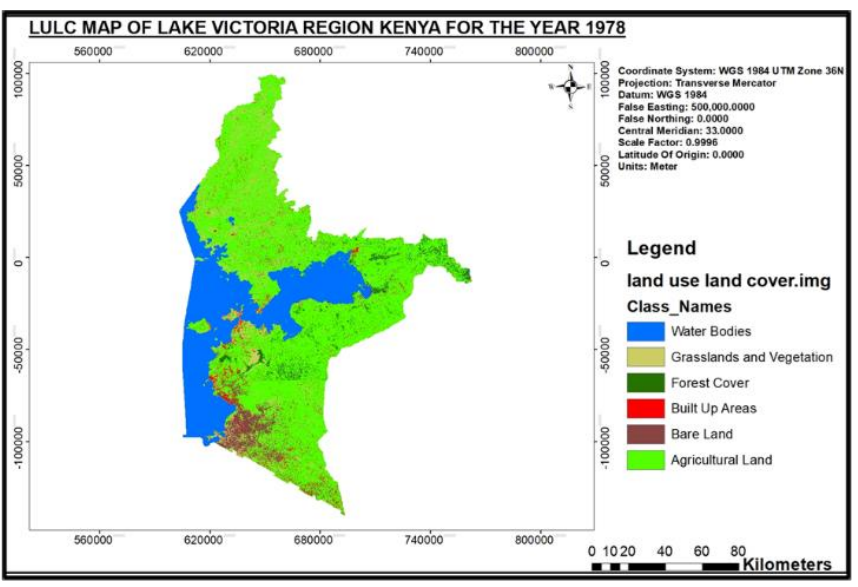

Figure 2. LULC classified map of the KLVB for 1978

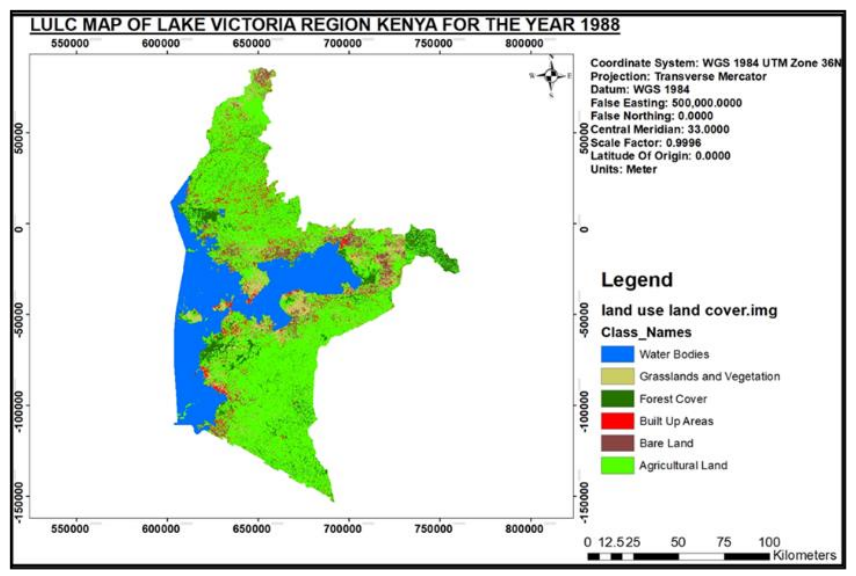

Figure 3. LULC classified map of the KLVB for 1988

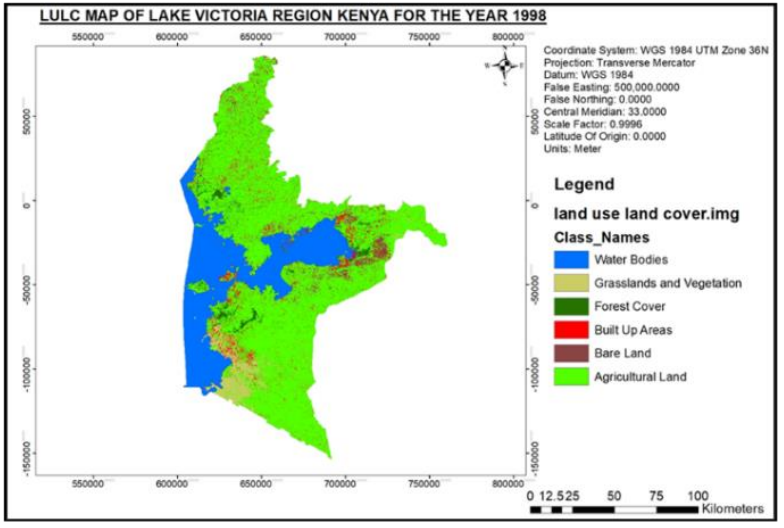

Figure 4. LULC classified map of the KLVB for 1998

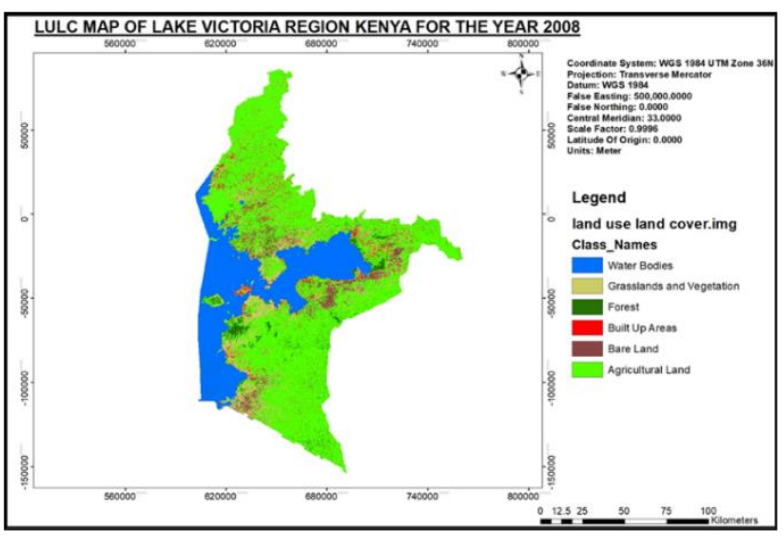

Figure 5. LULC classified map of the KLVB for 2008

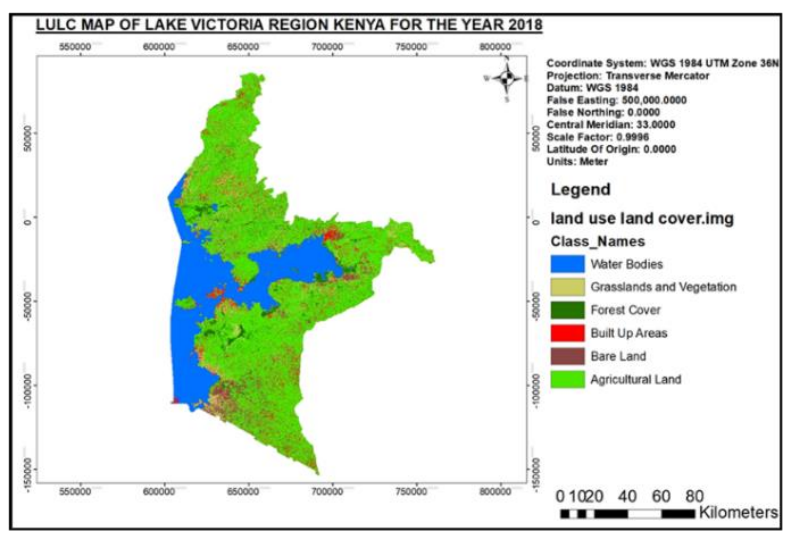

Figure 6. LULC classified map of the KLVB for 2018

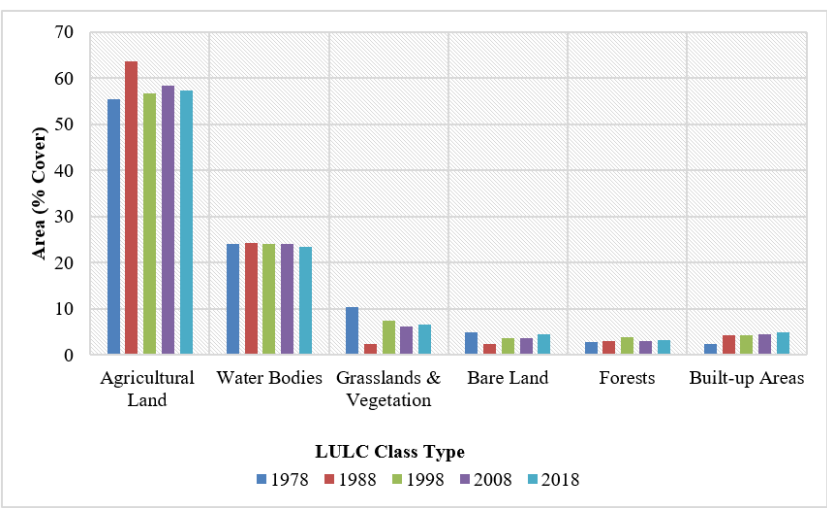

Figure 7. LULC in KLVB from 1978 - 2018 
Table 2. LULC statistics of KLVB between 1978 and 2018

\begin{tabular}{|c|c|c|c|c|c|c|c|c|c|c|}
\hline \multirow[b]{2}{*}{ Class Name } & \multicolumn{2}{|c|}{1978} & \multicolumn{2}{|c|}{1988} & \multicolumn{2}{|c|}{1998} & \multicolumn{2}{|c|}{2008} & \multicolumn{2}{|c|}{2018} \\
\hline & $\begin{array}{c}\text { Area } \\
\left(\mathbf{k m}^{2}\right)\end{array}$ & $\begin{array}{c}\% \\
\text { Cover }\end{array}$ & $\begin{array}{c}\text { Area } \\
\left(\mathbf{k m}^{2}\right)\end{array}$ & $\begin{array}{c}\% \\
\text { Cover }\end{array}$ & $\begin{array}{c}\text { Area } \\
\left(\mathbf{k m}^{2}\right)\end{array}$ & $\begin{array}{c}\% \\
\text { Cover } \\
\end{array}$ & $\begin{array}{c}\text { Area } \\
\left(\mathbf{k m}^{2}\right)\end{array}$ & $\begin{array}{c}\% \\
\text { Cover }\end{array}$ & $\begin{array}{c}\text { Area } \\
\left(\mathbf{k m}^{2}\right)\end{array}$ & $\begin{array}{c}\% \\
\text { Cover }\end{array}$ \\
\hline $\begin{array}{l}\text { Agricultural } \\
\text { Land }\end{array}$ & 8748.15 & 55.46 & 9868.42 & 63.65 & 8934.31 & 56.64 & 9223.35 & 58.48 & 9058.19 & 57.45 \\
\hline Water Bodies & 3789.51 & 24.03 & 3764.44 & 24.28 & 3784.03 & 23.99 & 3807.51 & 24.14 & 3706.60 & 23.51 \\
\hline $\begin{array}{c}\text { Grasslands \& } \\
\text { Vegetation }\end{array}$ & 1644.94 & 10.43 & 370.71 & 2.39 & 1177.93 & 7.47 & 984.08 & 6.24 & 1030.33 & 6.53 \\
\hline Bare Land & 771.83 & 4.89 & 370.71 & 2.39 & 585.08 & 3.71 & 590.15 & 3.74 & 700.18 & 4.44 \\
\hline Forests & 430.14 & 2.73 & 482.30 & 3.11 & 609.17 & 3.85 & 472.84 & 3.00 & 504.56 & 3.20 \\
\hline Built-up Areas & 388.15 & 2.46 & 647.65 & 4.18 & 682.19 & 4.33 & 695.11 & 4.41 & 766.82 & 4.86 \\
\hline Total & 15772.71 & 100 & 15772.71 & 100 & 15772.71 & 100 & 15772.71 & 100 & 15772.71 & 100 \\
\hline
\end{tabular}

Table 3. LULC decadal net changes in the KLVB for the period of $1978-2018$

\begin{tabular}{|c|c|c|c|c|c|c|c|c|c|c|}
\hline \multirow{2}{*}{$\begin{array}{l}\text { LULC } \\
\text { Class }\end{array}$} & \multicolumn{2}{|c|}{1978 - 1988} & \multicolumn{2}{|c|}{1988 - 1998} & \multicolumn{2}{|c|}{$1998-2008$} & \multicolumn{2}{|c|}{$2008-2018$} & \multicolumn{2}{|c|}{$\begin{array}{c}\text { (Overall Change) } \\
1978-2018\end{array}$} \\
\hline & $\begin{array}{l}\text { Area } \\
\left(\mathrm{km}^{2}\right)\end{array}$ & $\begin{array}{c}\% \\
\text { Change } \\
\end{array}$ & $\begin{array}{l}\text { Area } \\
\left(\mathrm{km}^{2}\right)\end{array}$ & $\begin{array}{c}\% \\
\text { Change }\end{array}$ & $\begin{array}{c}\text { Area } \\
\left(\mathrm{km}^{2}\right)\end{array}$ & $\begin{array}{c}\% \\
\text { Change } \\
\end{array}$ & $\begin{array}{l}\text { Area } \\
\left(\mathrm{km}^{2}\right)\end{array}$ & $\begin{array}{c}\% \\
\text { Change } \\
\end{array}$ & $\begin{array}{l}\text { Area } \\
\left(\mathrm{km}^{2}\right)\end{array}$ & $\begin{array}{c}\% \\
\text { Change } \\
\end{array}$ \\
\hline $\begin{array}{l}\text { Agricultur } \\
\text { al Land }\end{array}$ & 1120.27 & 12.81 & -934.11 & -9.47 & 289.04 & 3.24 & -165.16 & -1.79 & 310.05 & 3.54 \\
\hline $\begin{array}{l}\text { Water } \\
\text { Bodies }\end{array}$ & -25.07 & -0.66 & 19.59 & 0.52 & 23.49 & 0.62 & -100.91 & -2.65 & -82.91 & -2.19 \\
\hline $\begin{array}{c}\text { Grasslands } \\
\& \\
\text { Vegetation }\end{array}$ & -1274.23 & -77.46 & 807.22 & 217.75 & -193.85 & -16.46 & 46.243 & 4.70 & -614.62 & -37.36 \\
\hline $\begin{array}{l}\text { Bare Land } \\
\text { Forest }\end{array}$ & $\begin{array}{l}-401.12 \\
52.16\end{array}$ & $\begin{array}{c}-51.97 \\
12.13\end{array}$ & $\begin{array}{l}214.36 \\
126.87\end{array}$ & $\begin{array}{l}57.82 \\
26.30\end{array}$ & $\begin{array}{c}5.076 \\
-136.33\end{array}$ & $\begin{array}{c}0.87 \\
-22.38\end{array}$ & $\begin{array}{c}110.03 \\
31.72\end{array}$ & $\begin{array}{c}18.64 \\
6.71\end{array}$ & $\begin{array}{l}-71.65 \\
74.42\end{array}$ & $\begin{array}{l}-9.28 \\
17.30\end{array}$ \\
\hline $\begin{array}{l}\text { Built-up } \\
\text { Areas }\end{array}$ & 259.51 & 66.86 & 34.54 & 5.33 & 12.92 & 1.89 & 71.71 & 10.32 & 378.68 & 97.56 \\
\hline
\end{tabular}

Throughout the 40 years under study, the largest LULC class in the KLVB was agricultural land accounting for almost half of the total surface area of $15772.71 \mathrm{~km}^{2}$ (Table 2). This is because the communities living within the basin predominantly grow crops and keep livestock as the major sources of livelihood, besides fishing. The agricultural land has shown increasing trend over time though not in a steady or uniform manner since it sharply increases from 1978 to the peak of 1988 and then drops sharply in 1998 from where it stabilizes to be fairly constant throughout the period leading up to 2018 (Figure 2). Change detection data revealed that agricultural land has increased over time from 1978 to 2018 by $3.53 \%$ (Table 3 ) with potential implications on the environment.

The second largest LULC in the watershed has consistently been an area covered by water bodies which have fairly remained constant in areal coverage oscillating around $24 \%$ from 1978 to 2018. However, from the change detection results in Table 3, the area covered by water bodies has declined marginally over time from 1978 to 2018 by $2.19 \%$. Grasslands and vegetation constitute the third largest LULC class and there has been an overall steady decrease in coverage of this category in the basin over the past 40 years (Figure 2), losing about $37.36 \%$ by 2018 from the initial coverage of 1978 . The next largest LULC closely following grasslands and vegetation is bare land which has witnessed a slightly irregular trend over the past 40 years (Figure 2), culminating in $9.28 \%$ loss in coverage between 1978 and 2018 (Table 3). The least extensive LULC classes in terms of coverage are forests and built-up areas, respectively (Table 2). Results show that the areal coverage of both classes has been nearly equal (Figure 2). Furthermore, the two classes exhibited the same pattern of a steady increasing trend from 1988 to 2018 . According to the change detection results in Table 3 , forests and bare land have both increased over time from 1978 to 2018 by $17.30 \%$ and $97.56 \%$, respectively.

The natural environments in the basin are increasingly being converted to build environments and/or for agricultural production. These changes are driven by rapid population growth and urbanization. The high population growth around the KLVB is due to rural-urban migration as well as natural increase [45] while urbanization is seen to be a consequence of increased economic growth and the population. High population growth in the watershed region comes with increased demand for food, materials and development of infrastructure which consequently put pressure on the land resources leading to clearing of natural vegetation to provide space for agricultural expansion and settlement. The resultant losses in natural vegetation cover have the potential of contributing to loss of fragile ecosystems (such as wetlands) which in turn would lead to loss of ecological goods and services.

\subsection{Spatial -temporal trends and change detection}

Over the past four decades, the basin underwent substantial changes in areal coverage both spatially and temporally (Figure 8), reflecting a change in the environment. Those LULC changes have occurred due to pervasive urbanization in the watershed. Urbanization and environmental degradation are recognized as one of the challenges in the region where the watershed is located [46].

Further analyses of these results revealed specific net changes in the LULC classes for every decade from 1978 to 2018 (Table 3 and Figure 9). These changes can positively or negatively impact the environment. 


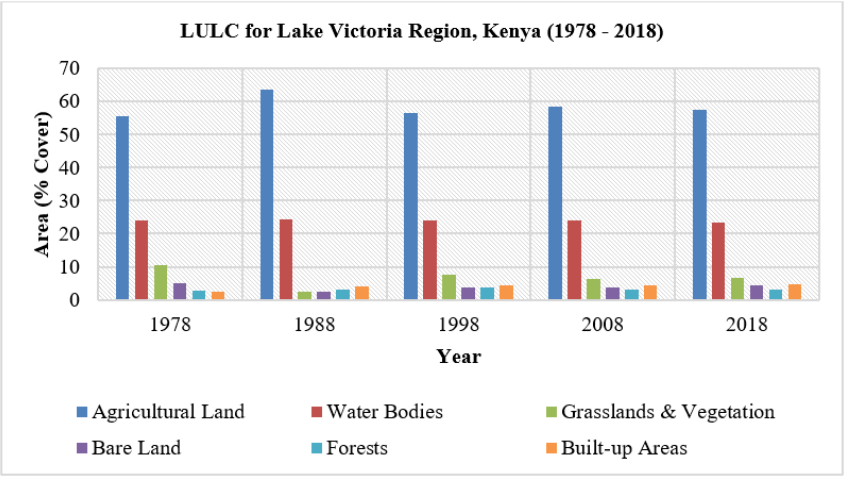

Figure 8. Trends of LULC classes in KLVB Watershed (1978-2018)

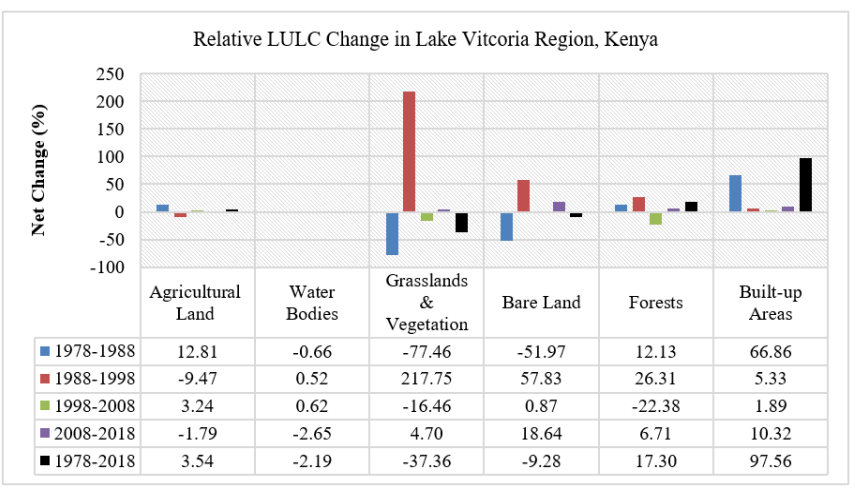

Figure 9. LULC decadal net changes in the KLVB for the period of $1978-2018$

\subsubsection{Pattern of LULC changes between 1978 and 1988}

Both positive and negative growth patterns were observed among the various LULC classes in Lake Victoria Basin during the period between 1978 and 1988 (Figure 9). The results indicate that the watershed was dominated by agricultural land as the most extensive LULC covering about $8748.15 \mathrm{~km}^{2}(55.46 \%)$ of the total area in 1978 but increased to $9868.42 \mathrm{~km}^{2}(65.65 \%)$ in 1988 , translating to a net gain in coverage of $12.81 \%$ during that period (Figure 9). Forests and built-up areas also exhibited positive growth patterns during this period, recording net gains of $12.13 \%$ and $66.86 \%$ respectively from their original coverage (Figure 9). The rest of the LULC classes recorded a negative growth pattern from 1978 to 1988 as follows (Figure 9); water bodies slightly decreased by $0.66 \%$, grasslands and vegetation decreased by $77.46 \%$, and bare land decreased by $51.97 \%$ (Figure 9 ).

From these analyses, it can be deduced that this decade experienced the greatest environmental change due to the conversion of areas under water bodies, grasslands and vegetation, and bare land to agricultural land, forests, and built-up areas. Basically, the land areas under built environment and agriculture were overtaking the natural landscapes. This could be attributed to the rapid population growth witnessed in this region which was estimated to be $5 \%$ per annum around that particular period [47]. It is documented that the environmental changes caught the attention of Kenya's second president Moi who then established a Permanent Presidential Commission on Soil Conservation and Afforestation (PPCSCA) in 1981 to encourage nationwide environmental conservation efforts [48].

\subsubsection{Pattern of LULC changes between 1988 and 1998}

In this period, all the LULC classes of the watershed exhibited positive growth patterns with exception of agricultural land, which showed negative growth pattern (Figure 9). Agricultural land covering about $9868.42 \mathrm{~km} 2$ $(65.65 \%)$ in 1988 dropped to about $8934.31 \mathrm{~km}^{2}(56.64 \%)$ of the total watershed area by 1998 (Table 2). There was a net loss of about $9.47 \%$ of agricultural land from 1988 (Figure 9). The rest of the LULC classes registered positive growth between 1988 and1998, with grassland and vegetation class recording the highest gain of $217.75 \%$ (Figure 9). Bare land and forest cover also showed a significant increase during this period (1988-1998) with a net gain of $57.82 \%$ and $26.30 \%$, respectively. The other two LULC classes recorded almost negligible positive growth pat-terns from 1988 to 1998 as follows: built-up areas grew by $5.33 \%$ while water bodies grew by $0.52 \%$. (Figure 9 ).

Generally, there was an increased coverage for all the LULC classes during this decade except for the agricultural land, which showed a decline in its coverage. This could be attributed to aggressive government afforestation and reforestation programs championed by the new Kenyan government of that time aimed at achieving the forest cover recommended by UNEP, which had been headquartered in Nairobi around that time. This came against the backdrop of the Beijer Institute report of 1979 that raised an alarming forecast predicting that by 2000 there wouldn't be any forested area in Kenya [49], but wasn't acted upon. This report would later trigger aggressive forest conservation and management measures in Kenya including the formulation of new policy and legal framework for sustainable forest management during the period of 1988 and 1999 [49].

\subsubsection{Pattern of LULC changes between 1998 and 2008}

During the period of 1998 to 2008, the study area underwent remarkable changes in the coverage of the LULC classes as shown in Figure 9. There was an erratic trend in the growth patterns of the LULC classes with four classes presenting small (almost negligible) positive growth patterns while two others showed considerable negative growth patterns. Positive growth trends in agricultural land dominated the coverage of the watershed during this decade, recording $8934.31 \mathrm{~km}^{2}$ in 1998 and increasing this coverage by $3.24 \%\left(+289.04 \mathrm{~km}^{2}\right)$ to $9223.35 \mathrm{~km} 2$ in 2008 (Table 3). The rest of the classes that showed minimal positive growth patterns during this period (1998 - 2008) are: built-up areas, bare land and water bodies recording marginal net gains of $1.89 \%, 0.87 \%$, and $0.62 \%$ respectively (Figure 9). Since these are pretty small percentages, it can be assumed that they occur within the error threshold of classification, hence implying that the four LULC classes remained relatively constant in the watershed during this period.

Nonetheless, during the same period (1998 - 2008), grasslands and vegetation declined considerably by losing $16.46 \%$ of its original cover of 1988 while forests declined substantially by losing $22.38 \%$ of its original coverage of 1988 (Figure 9). Generally, in this decade, great losses observed in both grasslands and vegetation, and forest portray a period of widespread deforestation and vegetation removal. This represents a major undoing of the gains realized in the previous decade (1988 - 1998). This is the consequence of policy lapses from the government coupled with a burgeoning population and massive urban expansion aimed at steering economic development in the region. This was done at the expense of conservation.

It has been reported [50] that this happened because the new 
Kenyan government of 2002 had drastically ripped off earlier conservation laws and policies and formulated their own new ones but these new laws and policies couldn't get enacted in good time and once, they finally got enacted, they couldn't get implemented because the government prioritized fulfilling their promise of economic development to the people, neglecting conservation. According to previous assessment, the losses in forest and grasslands and vegetation during this period must have been exacerbated by government action of grabbing 2000 ha from Mau forest land and using it to settle the Ogiek community [51]. Also, during this period, there was an upcoming election and so influential government officials were illegally allocated 10,000 ha as part of political cronyism [51].

\subsubsection{Pattern of LULC changes between 2008 and 2018}

LULC change detection for this period revealed that the study area experienced both great net gains and net losses among the various LULC classes (Figure 9). Contrary to the previous decade where both agricultural land and water bodies experienced positive growth trends, during this decade (2008 - 2018) they both started incurring losses in coverage though still marginal in nature (Figure 9). Agricultural land slightly dropped from the original coverage by $1.79 \%$ (Table 3 ). On the other hand, water bodies coverage also dropped by $2.65 \%$ from the original coverage of $3807.512 \mathrm{~km}^{2}$ in 2008 to $3706.604 \mathrm{~km}^{2}$ in 2018 . However, the rest of the LULC classes acquired net gains as follows: bare land in-creased by $18.64 \%$, built-up areas increased by $10.32 \%$, forests cover increased by $6.71 \%$, and lastly, grasslands and vegetation increased by $4.70 \%$. Results show that this is the only decade when the environment seems to have been impacted positively by the changing land uses since all the LULC classes gained coverage while agricultural land and are-as under water bodies fluctuated. It seems that the agricultural land might have been converted to built-up areas by the sprawling urban centers in the watershed.

The rapid spatial and temporal changes observed in the LULC of KLVB can be generally attributed to human activities and urban populations. This conforms to the findings of similar study in China [52]. Land use/land cover changes usually lead to various changes in the socio-economic aspects of a society, but this often comes at a cost on the environment [53]. The increased conversion of natural landscapes to agricultural production and/or built environments in the KLVB over time has potentially affected the environment around the watershed. The KLVB regularly experiences periodic floods, water pollution, air pollution, soil erosion and invasive species encroachment among others [35, 37, 54]. This study affirms that these environmental challenges must be due to the long-term land use/land cover changes in the region. The floods and water pollution in the watershed can be attributed to increased built-up environment which creates impervious surfaces in the form of roads and pavements, consequently preventing run-off water from seeping into the ground. This run-off water often carries pollutants and delivers them to water sources used by the residents, hence non-point water pollution [55]. Further, this water run-off contributes to flooding, which exacerbates the erosivity of the soil [53].

Urbanization of the watershed resulting from increased built-up environments also contributes to point-source pollution emanating from the municipal waste waters as well as increased air pollution from industries and motorized vehicles. This can lead to public health risks [56]. The rapid increase in coverage of agricultural land at the expense of natural landscapes amounts to habitat modification which could potentially lead to loss of biodiversity. Intensified agricultural practices, especially on the riparian landscapes, have the tendency of causing erosion which then contributes to sedimentation of water bodies, hence reduced water level or surface under waters. Furthermore, Lake Victoria has been previously found to be suffering from the invasive species called water hyacinth (Eichhornia crassipes) [37]. This might have been caused by pollution and agricultural practices around the lake which deliver nutrients from fertilizers and other chemicals into the lake water exacerbating eutrophication, thereby favoring growth of this invasive species. It has been previously established that the changing landscapes can contribute to the invasive species menace [57].

\subsection{Accuracy assessment of the LULC classification}

The Landsat images used in this study were authenticated using a confusion (error) matrix which is summarized and presented in Tables 4 and 5. Confusion matrix is suitable for classification of satellite images [2]. In accuracy assessment reports, the overall accuracies and the overall Kappa statis-tics / coefficient values are the most essential elements for testing classification accuracy since they represent a combination of all the aspects of the classification [43].

The results of the confusion matrix (Tables 4 and 5), show that the overall accuracy of the 1978, 1988, 1998, 2008 and 2018 Landsat classification images were $86.00 \%, 88.00 \%$, $87.00 \%, 92.00 \%$ and $92.00 \%$, respectively. For this study, all the imageries used for LULC classification registered an overall accuracy of over $86 \%$. An overall accuracy of over $80 \%$ is acceptable [58]. Moreover, overall classification accuracy in the range of between $84 \%$ and $85 \%$ is highly recommended [59]. From the foregoing, the LULC classification for this study was acceptable and hence reliable.

The confusion matrix results shown in Tables 4 and 5 also indicate that the overall Kappa coefficient values of the 1978, 1988, 1998, 2008 and 2018 Landsat classification images were $0.78,0.81,0.77,0.85$ and 0.87 , respectively. The study generally recorded values in the range of $0.77-0.81$ for all the classification imageries. Based on the agreement rating criteria for Kappa statistics / coefficient [60], this classification showed strong agreement with the reference data. The Kappa statistics/coefficient essentially measures the accuracy or agreement between data obtained from classified imageries to the data obtained from the ground reference points. Of all the classified images, the lowest producer's accuracy calculated for the six classes was 50\% recorded by forest in 1978 image and bare land in 1998 image while the highest producer's accuracy was the maximum $100 \%$ recorded by several LULC classes in various classification images. The producer's accuracy basically represents the map ac-curacy from the point of view of the image trainer (producer) [61]. On the other hand, user's accuracy calculated for the six classes in the classification images ranged from $50 \%$ (recorded by bare land in 1988 image) to $100 \%$ (also recorded by several LULC classes in various classification images). User's accuracy represents the error of commission [61]. Finally, the Kappa statistics values for the six classes for all the classification images were generally in the range of $0.49-1.00$ showing high reliability of the classification data. 
Table 4. Summarized confusion (error) matrix report for the classification maps for the years 1978, 1988 and 1998

\begin{tabular}{|c|c|c|c|c|c|c|c|c|c|}
\hline \multirow[b]{2}{*}{ LULC Class } & \multicolumn{3}{|c|}{1978} & \multicolumn{3}{|c|}{1988} & \multicolumn{3}{|c|}{1998} \\
\hline & $\begin{array}{c}\text { Producer's } \\
\text { Accuracy } \\
(\%)\end{array}$ & $\begin{array}{c}\text { User's } \\
\text { Accuracy } \\
(\%)\end{array}$ & $\begin{array}{l}\text { Kappa } \\
\text { statistic }\end{array}$ & $\begin{array}{l}\text { Producer's } \\
\text { Accuracy } \\
(\%)\end{array}$ & $\begin{array}{c}\text { User's } \\
\text { Accuracy } \\
(\%)\end{array}$ & $\begin{array}{l}\text { Kappa } \\
\text { statistic }\end{array}$ & $\begin{array}{c}\text { Producer's } \\
\text { Accuracy } \\
(\%)\end{array}$ & $\begin{array}{c}\text { User's } \\
\text { Accuracy } \\
(\%)\end{array}$ & $\begin{array}{l}\text { Kappa } \\
\text { statistic }\end{array}$ \\
\hline $\begin{array}{l}\text { Agricultural } \\
\text { Land }\end{array}$ & 96.1 & 83.1 & 0.65 & 95.9 & 87.0 & 0.75 & 98.3 & 86.6 & 0.67 \\
\hline Water Bodies & 77.8 & 91.3 & 0.88 & 82.8 & 88.9 & 0.84 & 84.2 & 80.0 & 0.75 \\
\hline $\begin{array}{l}\text { Grasslands \& } \\
\text { Vegetation }\end{array}$ & 80.0 & 88.9 & 0.88 & 100.0 & 100.0 & 1.00 & 60.0 & 100.0 & 1.00 \\
\hline Bare Land & 80.0 & 80.0 & 0.79 & 100.0 & 50.0 & 0.49 & 50.0 & 100.0 & 1.00 \\
\hline Forests & 50.0 & 100.0 & 1.00 & 66.7 & 100.0 & 1.00 & 60.0 & 100.0 & 1.00 \\
\hline Built-up Areas & 100.0 & 100.0 & 1.00 & 100.0 & 50.0 & 0.49 & 66.7 & 100.0 & 1.00 \\
\hline $\begin{array}{c}\text { Overall } \\
\text { Accuracy }(\%)\end{array}$ & \multicolumn{3}{|c|}{86.0} & \multicolumn{3}{|c|}{88.0} & \multicolumn{3}{|c|}{87.0} \\
\hline $\begin{array}{c}\text { Overall Kappa } \\
\text { statistic }\end{array}$ & \multicolumn{3}{|c|}{0.78} & \multicolumn{3}{|c|}{0.81} & \multicolumn{3}{|c|}{0.77} \\
\hline
\end{tabular}

Table 5. Summarized confusion (error) matrix report for the classification maps for the years 2008 and 2018

\begin{tabular}{|c|c|c|c|c|c|c|}
\hline \multirow[b]{2}{*}{ LULC Class } & \multicolumn{3}{|c|}{2008} & \multicolumn{3}{|c|}{2018} \\
\hline & $\begin{array}{c}\text { Producer's } \\
\text { Accuracy }(\%)\end{array}$ & $\begin{array}{c}\text { User's Accuracy } \\
(\%)\end{array}$ & $\begin{array}{c}\text { Kappa } \\
\text { statistic }\end{array}$ & $\begin{array}{c}\text { Producer's } \\
\text { Accuracy }(\%)\end{array}$ & $\begin{array}{c}\text { User's Accuracy } \\
(\%)\end{array}$ & $\begin{array}{l}\text { Kappa } \\
\text { statistic }\end{array}$ \\
\hline Agricultural Land & 96.4 & 91.0 & 0.76 & 100.0 & 94.9 & 0.88 \\
\hline Water Bodies & 91.3 & 91.3 & 0.89 & 82.6 & 95.0 & 0.94 \\
\hline $\begin{array}{l}\text { Grasslands \& } \\
\text { Vegetation }\end{array}$ & 66.7 & 100.0 & 1.00 & 100.0 & 75.0 & 0.73 \\
\hline Bare Land & - & - & - & 71.4 & 100.0 & 1.00 \\
\hline Forests & 66.7 & 100.0 & 1.00 & 66.7 & 80.0 & 0.79 \\
\hline Built-up Areas & 66.7 & 100.0 & 1.00 & 100.0 & 66.7 & 0.66 \\
\hline $\begin{array}{l}\text { Overall Accuracy } \\
(\%)\end{array}$ & \multicolumn{3}{|c|}{92.0} & \multicolumn{3}{|c|}{92.0} \\
\hline $\begin{array}{c}\text { Overall Kappa } \\
\text { statistic }\end{array}$ & \multicolumn{3}{|c|}{0.85} & \multicolumn{3}{|c|}{0.87} \\
\hline
\end{tabular}

\section{CONCLUSIONS}

Remote sensing provides a rapid and effective way of monitoring LULC to detect environmental changes. This is demonstrated by the detailed analysis of the LULC changes in the Lake Victoria watershed (Kenyan region) which was carried out in this study using high resolution classified Landsat satellite images. However, the use of remote sensing in monitoring is limited by the fact that it requires a certain level of skills to interpret the imagery and that its accuracy has to be verified using ground survey data.

The study shows that Lake Victoria Basin has undergone considerable land use/land cover change from 1978-2018. The changing landscapes in the basin are characterized by conversion of natural environments to build environments and driven by human activities, urban populations and public policy decisions. The surface areas under built-ups areas, forests and agricultural land are increasing while areas under grasslands and vegetation, bare land and water bodies are diminishing in the KLVB. These point to a steadily urbanizing watershed. These changes are responsible for environmental degradation in the basin which includes increased pollution, reduced water quality, increased erosion and emergence of invasive species. Countering this degradation would require urgent measures aimed at diversification of livelihoods as well as environmental conservation in the basin area. To do this, the study recommends the establishment of a land use system that creates a balance between the ecological realm and sustainable development. The ecological conservation aspects need to be entwined with the land use/land cover management in order to protect biodiversity threatened by habitat modification. This can be accomplished by local land use planning which needs to allocate various crop growing, forestry and controlled grazing activities to suitable lands so as to control erosion, design the siting of various infrastructures such as roads, water supply and local markets to maximize soil and water conservation, and finally apply new technology such as remote sensing in carrying out restoration and management of degraded areas.

\section{ACKNOWLEDGMENT}

This study was achieved through the dedicated effort of the following research assistants: Jeremiah Lekolwane (Maseno University, Kenya), Samuel Methusela (University of Nairobi, Kenya) and Phillip Zeph (ICRISAT, Kenya). Additional expert opinion and technical research advice was provided by Prof. Anthony Gidudu (Makerere University, Uganda).

\section{REFERENCES}

[1] Cihlar, J., Jansen, L.J. (2001). From land cover to land use: a methodology for efficient land use mapping over large areas. The Professional Geographer, 53(2): 275289. https://doi.org/10.1111/0033-0124.00285

[2] Campbell, J.B., Wynne, R.H. (2011). Introduction to remote sensing. Guilford Press. https://doi.org/10.1111/0031-868X.t01-1-00020_1 
[3] Lillesand, T., Kiefer, R.W., Chipman, J. (2015). Remote Sensing and Image Interpretation. John Wiley \& Sons. https://doi.org/10.2307/634969

[4] Sajjad, H., Iqbal, M. (2012). Impact of urbanization on land use/land cover of Dudhganga watershed of Kashmir Valley, India. International Journal of Urban Sciences, 16(3): 321-339. https://doi.org/10.1080/12265934.2012.743749

[5] Zhao, G.X., Lin, G., Warner, T. (2004). Using Thematic Mapper data for change detection and sustainable use of cultivated land: a case study in the Yellow River delta, China. International Journal of Remote Sensing, 25(13): 2509-2522.

https://doi.org/10.1080/01431160310001619571

[6] Dwivedi, R.S., Sreenivas, K., Ramana, K.V. (2005). Cover: Land-use/land-cover change analysis in part of Ethiopia using Landsat Thematic Mapper data. International Journal of Remote Sensing, 26(7): 12851287. https://doi.org/10.1080/01431160512331337763

[7] Reis, S. (2008). Analyzing land use/land cover changes using remote sensing and GIS in Rize, North-East Turkey. Sensors, 8(10): 6188-6202. https://doi.org/10.3390/s8106188

[8] Meshesha, T.W., Tripathi, S.K., Khare, D. (2016). Analyses of land use and land cover change dynamics using GIS and remote sensing during 1984 and 2015 in the Beressa Watershed Northern Central Highland of Ethiopia. Modeling Earth Systems and Environment, 2(4): 1-12. https://doi.org/10.1007/s40808-016-0233-4

[9] Zhang, T., Zhang, X., Xia, D., Liu, Y. (2014). An analysis of land use change dynamics and its impacts on hydrological processes in the Jialing River Basin. Water, 6(12): 3758-3782. https://doi.org/10.3390/w6123758

[10] Kennedy, R.E., Andréfouët, S., Cohen, W.B., Gómez, C., Griffiths, P., Hais, M. (2014). Bringing an ecological view of change to Landsat-based remote sensing. Frontiers in Ecology and the Environment, 12(6): 339346. https://doi.org/10.1890/130066

[11] Rogan, J., Chen, D. (2004). Remote sensing technology for mapping and monitoring land-cover and land-use change. Progress in Planning, 61(4): 301-325. https://doi.org/10.1016/S0305-9006(03)00066-7

[12] Dezso, Z., Bartholy, J., Pongracz, R., Barcza, Z. (2005). Analysis of land-use/land-cover change in the Carpathian region based on remote sensing techniques. Physics and Chemistry of the Earth, Parts A/B/C, 30(1-3): 109-115. https://doi.org/10.1016/j.pce.2004.08.017

[13] Lambin, E.F., Geist, H.J., Lepers, E. (2003). Dynamics of land-use and land-cover change in tropical regions. Annual Review of Environment and Resources, 28(1): 205-241.

https://doi.org/10.1146/annurev.energy.28.050302.1054 59

[14] Mallupattu, P.K., Sreenivasula Reddy, J.R. (2013). Analysis of land use/land cover changes using remote sensing data and GIS at an Urban Area, Tirupati, India. The Scientific World Journal. https://doi.org/10.1155/2013/268623

[15] Sudhira, H.S., Ramachandra, T.V., Jagadish, K.S. (2004). Urban sprawl: metrics, dynamics and modelling using GIS. International Journal of Applied Earth Observation and Geoinformation, 5(1): 29-39. https://doi.org/10.1016/j.jag.2003.08.002

[16] Martinuzzi, S., Gould, W.A., González, O.M.R. (2007).
Land development, land use, and urban sprawl in Puerto Rico integrating remote sensing and population census data. Landscape and Urban Planning, 79(3-4): 288-297. https://doi.org/10.1016/j.landurbplan.2006.02.014

[17] Fan, F., Weng, Q., Wang, Y. (2007). Land use and land cover change in Guangzhou, China, from 1998 to 2003, based on Landsat TM/ETM+ imagery. Sensors, 7(7): 1323-1342.

[18] Mubako, S., Belhaj, O., Heyman, J., Hargrove, W., Reyes, C. (2018). Monitoring of land use/land-cover changes in the arid transboundary middle Rio grande basin using remote sensing. Remote Sensing, 10(12): 2005. https://doi.org/10.3390/rs10122005

[19] Pauleit, S., Ennos, R., Golding, Y. (2005). Modeling the environmental impacts of urban land use and land cover change - a study in Merseyside, UK. Landscape and Urban Planning, 71(2-4): 295-310. https://doi.org/10.1016/j.landurbplan.2004.03.009

[20] Koellner, T., Scholz, R.W. (2008). Assessment of land use impacts on the natural environment. The International Journal of Life Cycle Assessment, 13(1): 32-48. https://doi.org/10.1065/lca2006.12.292.2

[21] Wu, Y., Li, S., Yu, S. (2016). Monitoring urban expansion and its effects on land use and land cover changes in Guangzhou city, China. Environmental Monitoring and Assessment, 188(1): 54. https://doi.org/10.1007/s10661-015-5069-2

[22] Rai, R., Zhang, Y., Paudel, B., Acharya, B.K., Basnet, L. (2018). Land use and land cover dynamics and assessing the ecosystem service values in the trans-boundary Gandaki River Basin, Central Himalayas. Sustainability, 10(9): 3052. https://doi.org/10.3390/su10093052

[23] Fisseha, G., Gebrekidan, H., Kibret, K., Yitaferu, B., Bedadi, B. (2011). Analysis of land use/land cover changes in the Debre-Mewi watershed at the upper catchment of the Blue Nile Basin, North West Ethiopia. J. Biodivers. Environ. Sci, 1(6): 184-198.

[24] Elhaja, M.E., Csaplovics, E., Abdelkareem, O.E., Adam, H.E., El, A., Khalifa, K.S.O. (2017). Land use land cover changes detection in White Nile State, Sudan using remote sensing and GIS techniques. Int. J. Environ. Monit. Prot, 4: 14-19.

[25] Nicholas Kiggundu, I.I., Anaba, L.A., Banadda, N., Wanyama, J., Kabenge, I. (2018). Assessing land use and land cover changes in the Murchison Bay catchment of Lake Victoria basin in Uganda. Journal of Sustainable Development, $\quad 11(1)$ : 44-55. https://doi.org/10.5539/jsd.v11n1p44

[26] Mohajane, M., Essahlaoui, A., Oudija, F., Hafyani, M.E., Hmaidi, A. E., Ouali, A.E. (2018). Land use/land cover (LULC) using landsat data series (MSS, TM, ETM+ and OLI) in Azrou Forest, in the Central Middle Atlas of Morocco. Environments, 5(12): 131-147. https://doi.org/10.3390/environments5120131

[27] Muriithi, F.K. (2016). Land use and land cover (LULC) changes in semi-arid sub-watersheds of Laikipia and Athi River basins, Kenya, as influenced by expanding intensive commercial horticulture. Remote Sensing Applications: Society and Environment, 3: 73-88. https://doi.org/10.1016/j.rsase.2016.01.002

[28] Were, K.O., Dick, Ø.B., Singh, B.R. (2013). Remotely sensing the spatial and temporal land cover changes in Eastern Mau forest reserve and Lake Nakuru drainage basin, Kenya. Applied Geography, 41: 75-86. 
https://doi.org/10.1016/j.apgeog.2013.03.017

[29] Baldyga, T.J., Miller, S.N., Driese, K.L., Gichaba, C.M. (2008). Assessing land cover change in Kenya's Mau Forest region using remotely sensed data. African Journal of Ecology, 46(1): 46-54. https://doi.org/10.1111/j.1365-2028.2007.00806.x

[30] Olang, L.O., Fürst, J. (2011). Effects of land cover change on flood peak discharges and runoff volumes: model estimates for the Nyando River Basin, Kenya. Hydrological Processes, 25(1): 80-89. https://doi.org/10.1002/hyp.7821

[31] Musa, M.K., Odera, P.A. (2015). Land use land cover changes and their effects on agricultural land a case study of Kiambu County Kenya. 9th Annual Conference Kabarak University 2019. 62: 41-48. http://ir.kabarak.ac.ke/handle/123456789/353

[32] Muriuki, G., Seabrook, L., McAlpine, C., Jacobson, C., Price, B., Baxter, G. (2011). Land cover change under unplanned human settlements: A study of the Chyulu Hills squatters, Kenya. Landscape and Urban Planning, 99(2):

https://doi.org/10.1016/j.landurbplan.2010.10.002

[33] Swallow, B.M., Sang, J.K., Nyabenge, M., Bundotich, D.K., Duraiappah, A.K., Yatich, T.B. (2009). Tradeoffs, synergies and traps among ecosystem services in the Lake Victoria basin of East Africa. Environmental Science \& Policy, 12(4): 504-519. https://doi.org/10.1016/j.envsci.2008.11.003

[34] Twesigye, C.K., Onywere, S.M., Getenga, Z.M., Mwakalila, S.S., Nakiranda, J.K. (2011). The impact of land use activities on vegetation cover and water quality in the Lake Victoria watershed. The Open Environmental Engineering Journal, 4(1): 66-77. https://doi.org/10.2174/1874829501104010066

[35] Okungu, J.O., Njoka, S., Abuodha, J.O.Z., Hecky, R.E. (2005). An introduction to Lake Victoria catchment, water quality, physical limnology and ecosystem status (Kenyan sector).

[36] Mati, B.M., Mutie, S., Gadain, H., Home, P., Mtalo, F. (2008). Impacts of land-use/cover changes on the hydrology of the transboundary Mara River, Kenya/Tanzania. Lakes \& Reservoirs: Research \& Management, 13(2): 169-177. https://doi.org/10.1111/j.1440-1770.2008.00367.x

[37] Juma, D.W., Wang, H., Li, F. (2014). Impacts of population growth and economic development on water quality of a lake: case study of Lake Victoria Kenya water. Environmental Science and Pollution Research, 21(8): 5737-5746. https://doi.org/10.1007/s11356-0142524-5

[38] Muyodi, F.J., Bugenyi, F.W., Hecky, R.E. (2010). Experiences and lessons learned from interventions in the Lake Victoria Basin: the Lake Victoria environmental management project. Lakes \& Reservoirs: Research \& Management, 15(2): 77-88. https://doi.org/10.1111/j.1440-1770.2010.00425.x

[39] Zhou, M., Brandt, P., Pelster, D., Rufino, M.C., Robinson, T., Butterbach-Bahl, K. (2014). Regional nitrogen budget of the Lake Victoria Basin, East Africa: syntheses, uncertainties and perspectives. Environmental Research Letters, 9(10): 105009. https://doi.org/10.1088/1748-9326/9/10/105009

[40] United States Geological Society. (2020). Mapping, Remote Sensing, and Geospatial Data. Available online: https://www.usgs.gov/faqs/what-are-band-designationslandsat-satellites?qt-news_science_products $=0 \#$ qtnews_science_products.

[41] Manandhar, R., Odeh, I.O., Ancev, T. (2009). Improving the accuracy of land use and land cover classification of Landsat data using post-classification enhancement. Remote Sensing, 1(3): 330-344. https://doi.org/10.3390/rs1030330

[42] Lu, D., Weng, Q. (2007). A survey of image classification methods and techniques for improving classification performance. International Journal of $\begin{array}{lll}\text { Remote } & \text { Sensing, } & \text { 28(5): }\end{array}$ https://doi.org/10.1080/01431160600746456

[43] Congalton, R.G., Green, K. (2019). Assessing the Accuracy of Remotely Sensed Data: Principles and Practices. CRC Press. https://doi.org/10.1111/j.14779730.2010.00574 2.x

[44] Nicholas Kiggundu, I.I., Anaba, L.A., Banadda, N., Wanyama, J., Kabenge, I. (2018). Assessing land use and land cover changes in the Murchison Bay catchment of Lake Victoria basin in Uganda. Journal of Sustainable Development, 11(1): 56-63. https://doi.org/10.5539/jsd.v11n1p44

[45] Government of Kenya. (2012). Kenya Demographic and Health Survey 2012 (Nairobi, Kenya: Central Bureau of Statistics and Ministry of Health, Kenya). pp. 30-35.

[46] County, M. (2013). County integrated development plan. County Government of. http://10.0.0.19/handle/123456789/1200.

[47] Rakama, S.O., Obiri, J.F., Mugalavai, E.M. (2017). Evaluation of land use change pattern of Kajulu-Riat hill peri-urban area near Kisumu City, Kenya. IJSRIT, 4(7): 42-52.

[48] Nasong'o, S.W. (2012). Ecological Roots of Social Conflict in Kenya: Pastoralism, Land, and the Development Paradox. In "Perspectives on African Environment, Science and Technology," Toyin Falola and Maurice Amutabi, eds. Trenton, NJ: Africa World Press.

[49] Ludeki, J.V., Wamukoya, G.M., Walubengo, D. (2005). Environmental management in Kenya: A framework for sustainable Forest Management in Kenya. Understanding the Draft Forest Policy and Forests Act.

[50] Kosgey, B.A. (2015). An Assessment of the Implementation of Participatory Forest Management (PFM) By Ngong Road Community Forest Association (CFA) In Nairobi County, Kenya. Kenya: Unpublished Thesis.

[51] Kenya Institute of Public Policy Research and Analysis (KIPPRA). (2010). Ndung'u Report on Land Grabbing in Kenya: Legal and Economic Analysis. Nairobi: KIPPRA. pp. 225-247.

[52] Zhang, Z., Liu, S., Wei, J., Xu, J., Guo, W., Bao, W., Jiang, Z. (2016). Mass change of glaciers in Muztag AtaKongur Tagh, Eastern Pamir, China from 1971/76 to 2013/14 as derived from remote sensing data. PloS one, 11(1): e0147327. https://doi.org/10.1371/journal.pone.0147327

[53] U.S. Environmental Protection Agenc, (2020). Report on the Environment. Available online: https://www.epa.gov/report-environment/land-use.

[54] Babu, J.M, Sitoki, L.M, Ogendi, G.M., Getabu, A.M., Boera, P.N. Akunga, G.N., Nyaundi, J.K., Njiru, J.M., Mwayuli, G.A., Olilo, C. (2015). Effects of point source 
pollution on water quality, phytoplankton diversity and abundance in lake Victoria, Kenya, International Journal of Fisheries and Aquatic Studies, 2(5): 57-64.

[55] U.S. Environmental Protection Agency. (2005). Estimating and projecting impervious cover in the Southeastern United States. EPA/600/R-05/061. Athens, p. 133.

[56] Schwartz, J. (2004). Air pollution and children's health. Pediatrics, 113(Supplement 4): 1037-1043.

[57] Westbrooks, R.G. (1998). Invasive plants: changing the landscape of America: Fact book. Federal Interagency Committee for the Management of Noxious and Exotic Weeds. Washington. https://doi.org/10.1021/bk-20111073.ch011

[58] Turan, S.Ö., Günlü, A. (2010). Spatial and temporal dynamics of land use pattern response to urbanization in
Kastamonu. African Journal of Biotechnology, 9(5): 640-647. https://doi.org/10.5897/AJB09.1478

[59] Wickham, J.D., Stehman, S.V., Gass, L., Dewitz, J., Fry, J.A., Wade, T.G. (2013). Accuracy assessment of NLCD 2006 land cover and impervious surface. Remote Sensing of Environment, 130: 294-304. https://doi.org/10.1016/j.rse.2012.12.001

[60] Landis, J.R., Koch, G.G. (1977). The measurement of observer agreement for categorical data. Biometrics, 33(1): 159-174. https://doi.org/10.2307/2529310

[61] Ikiel, C., Ustaoglu, B., Dutucu, A.A., Kilic, D.E. (2013). Remote sensing and GIS-based integrated analysis of land cover change in Duzce plain and its surroundings (north western Turkey). Environmental Monitoring and Assessment, 185(2): 1699-1709. 